\title{
Effectiveness, tolerability and safety to Direct Acting Antivirals in Mexican individuals with Hepatitis $C$ virus genotype-1 and previous Pegylated Interferon and Ribavirin therapy
}

Daniel Melendez Mena ${ }^{1,2}$, Miguel A Mendoza-Torres ${ }^{1,2}$, Virginia Sedeno Monge ${ }^{3}$, Víctor Hugo García y García ${ }^{2}$, Elain Rivera-García ${ }^{3}$, Laura Sánchez-Reza ${ }^{2}$, María del Carmen Baxin Domínguez ${ }^{4}$, Belinda Guzman-Flores ${ }^{5}$, Ygnacio Martinez-Laguna ${ }^{6}$, José Manuel Coronel Espinoza ${ }^{7}$, Iván Galindo-Santiago ${ }^{8}$, Juan Carlos Flores-Alonso ${ }^{8}$, Verónica Vallejo-Ruiz ${ }^{8}$, Paulina Cortes-Hernandez ${ }^{9}$, Julio Reyes-Leyva ${ }^{8}$, Francisca Sosa-Jurado ${ }^{8}$, Gerardo SantosLópez ${ }^{\text {Corresp. } 8}$

${ }^{1}$ Centro Interdisciplinario de Posgrados, Facultad de Medicina, Universidad Popular Autonóma del Estado de Puebla, Puebla, Puebla, Mexico

2 Servicio de Gastroenterología, Centro Médico Nacional General de División Manuel Ávila Camacho, Instituto Mexicano del Seguro Social, Puebla, Puebla, Mexico

3 Decanato de Ciencias Médicas, Universidad Popular Autonóma del Estado de Puebla, Puebla, Puebla, Mexico

4 Centro Médico Nacional La Raza, Instituto Mexicano del Seguro Social, Ciudad de México, Mexico

5 Banco de Sangre, Centro Médico Nacional General de División Manuel Ávila Camacho, Instituto Mexicano del Seguro Social, Puebla, Puebla, Mexico

6 Instituto de Ciencias, Benemerita Universidad Autónoma de Puebla, Puebla, Puebla, Mexico

7 Hospital General Regional \# 1, Instituto Mexicano del Seguro Social, Tarímbaro, Michoacán, Mexico

8 Laboratorio de Biología Molecular y Virología, Centro de Investigación Biomédica de Oriente, Instituto Mexicano del Seguro Social, Metepec, Puebla, Mexico

9 Laboratorio de Biología Celular, Centro de Investigación Biomédica de Oriente, Instituto Mexicano del Seguro Social, Metepec, Puebla, Mexico

Corresponding Author: Gerardo Santos-López

Email address: gerardo.santos.lopez@gmail.com

Background. Direct Acting Antivirals (DAAs) represent a large improvement in the treatment of chronic hepatitis $C$, resulting in $>90 \%$ sustained virological response (SVR). There are no reports on the real-world DAA response for Mexico and few reports exist for Latin America. The aim of the study was to report SVR, and immediate benefits with the DAA treatments sofosbuvir, simeprevir, with/without ribavirin (SOF/SMV $\pm R B V$ ) and ombitasvir, paritaprevir, ritonavir, dasabuvir with/without RBV (OBV/PTV/r/DSV \pm RBV) in patients with viral genotype $1 \mathrm{a}$ or $1 \mathrm{~b}$, and who did not respond to previous peginterferon/ribavirin (PegIFN $\alpha 2 a+R B V$ ) therapy. Methods. A descriptive, ambispective, longitudinal study was conducted. A cohort of 261 adult patients received PegIFN $\alpha 2 a+R B V$ therapy before 2014; 167 (64\%) did not respond, 83 of these, were subsequently treated with SOF/SMV \pm RBV or OBV/PTV/r/DSV \pm RBV. Child-Pugh-Score (CPS), Fibrosis-4 (FIB-4), and AST to Platelet Ratio Index (APRI) were evaluated before and after treatment. Results. SVR with PegIFNa2a+RBV was 36\%, and $97.5 \%$ with DAAs. CPS, FIB-4 and APRI improved significantly after DAA treatment, mainly because of liver transaminase reduction.

Conclusions. DAA treatment showed excellent SVR rates in Mexican patients who had not
Peer reviewing PDF (2021:04:59862:1: 1 : NEW 9 ju 2021$)$ 
responded to PegIFNa2a+RBV therapy. Improvement in CPS, FIB-4 and APRI without improvement in fibrosis was observed in cirrhotic and non-cirrhotic patients, as well as considerable reduction in liver transaminases, which suggests a reduction in hepatic necroinflammation. 
1 Effectiveness, tolerability and safety to Direct Acting

2 Antivirals in Mexican individuals with Hepatitis $\mathbf{C}$ virus

3 genotype-1 and previous Pegylated Interferon and

4 Ribavirin therapy

5

6

7

8

9

10

11

12

13

14

15

Daniel Meléndez-Mena ${ }^{1,2}$, Miguel A. Mendoza-Torres ${ }^{1,2}$, Virginia Sedeño-Monge ${ }^{3}$, Víctor H. García y García ${ }^{1}$, Elain N. Rivera García ${ }^{3}$, Laura Sánchez-Reza ${ }^{1}$, María C. Baxin-Dominguez ${ }^{4}$, Belinda Guzmán-Flores ${ }^{5}$, Ygnacio Martínez-Laguna ${ }^{6}$, José M. Coronel-Espinoza ${ }^{7}$, Iván GalindoSantiago $^{8}$, Juan C. Flores-Alonso ${ }^{8}$, Verónica Vallejo-Ruiz ${ }^{8}$, Paulina Cortés-Hernández ${ }^{9}$, Julio Reyes-Leyva ${ }^{8}$, Francisca Sosa-Jurado $^{8}$ and Gerardo Santos-López ${ }^{8 *}$

${ }^{1}$ Servicio de Gastroenterología, Unidad Médica de Alta Especialidad, Centro Médico Nacional "General de División Manuel Ávila Camacho", Instituto Mexicano del Seguro Social (IMSS). Puebla, Puebla, México.

${ }^{2}$ Centro Interdisciplinario de Posgrados, Facultad de Medicina, Universidad Popular Autónoma del Estado de Puebla. Puebla, Puebla, México.

${ }^{3}$ Decanato de Ciencias Médicas, Facultad de Medicina, Universidad Popular Autónoma del Estado de Puebla. Puebla, Puebla, México.

${ }^{4}$ Clínica del Hígado y hepatopatías autoinmunes, Unidad Médica de Alta Especialidad, Dr. Antonio Fraga Mouret, Centro Médico Nacional " La Raza", IMSS.

${ }^{5}$ Banco de Sangre, Unidad Médica de Alta Especialidad, Centro Médico Nacional "General de División Manuel Ávila Camacho", Instituto Mexicano del Seguro Social (IMSS). Puebla, Puebla, México.

${ }^{6}$ Centro de Investigaciones en Ciencias Microbiológicas, Instituto de Ciencias, Benemérita Universidad Autónoma de Puebla. Puebla, Puebla, México.

${ }^{7}$ Servicio de Gastroenterología, Hospital General Regional No 1, El Charo, IMSS. Tarímbaro, Michoacán de Ocampo, México.

${ }^{8}$ Laboratorio de Biología Molecular y Virología, Centro de Investigación Biomédica de Oriente, IMSS. Metepec, Atlixco, Puebla, México.

${ }^{9}$ Laboratorio de Biología Celular, Centro de Investigación Biomédica de Oriente, IMSS.

Metepec, Atlixco, Puebla, México.

Corresponding Author:

Gerardo Santos-López

Laboratorio de Biología Molecular y Virología, Centro de Investigación Biomédica de Oriente, IMSS. Km 4.5 Carretera Federal Atlixco-Metepec, Hospital General de Zona No 5, Metepec, Atlixco; 74360 Puebla, México.

Email address: gerardo.santos.lopez@gmail.com

\section{Abstract}

Background. Direct Acting Antivirals (DAAs) represent a large improvement in the treatment of chronic hepatitis $\mathrm{C}$, resulting in $>90 \%$ sustained virological response (SVR). There are no 
43 reports on the real-world DAA response for Mexico and few reports exist for Latin America. The

44 aim of the study was to report SVR, and immediate benefits with the DAA treatments

45 sofosbuvir, simeprevir, with/without ribavirin (SOF/SMV $\pm \mathrm{RBV}$ ) and ombitasvir, paritaprevir,

46 ritonavir, dasabuvir with/without RBV (OBV/PTV/r/DSV $\pm \mathrm{RBV})$ in patients with viral genotype

47 1a or $1 \mathrm{~b}$, and who did not respond to previous peginterferon/ribavirin (PegIFNa2a+RBV)

48 therapy.

49 Methods. A descriptive, ambispective, longitudinal study was conducted. A cohort of 261 adult

50 patients received PegIFNa2a+RBV therapy before 2014; 167 (64\%) did not respond, 83 of these, 51 were subsequently treated with $\mathrm{SOF} / \mathrm{SMV} \pm \mathrm{RBV}$ or OBV/PTV/r/DSV $\pm \mathrm{RBV}$. Child-Pugh-Score

52 (CPS), Fibrosis-4 (FIB-4), and AST to Platelet Ratio Index (APRI) were evaluated before and 53 after treatment.

54 Results. SVR with PegIFNa2a+RBV was 36\%, and 97.5\% with DAAs. CPS, FIB-4 and APRI 55 improved significantly after DAA treatment, mainly because of liver transaminase reduction.

56 Conclusions. DAA treatment showed excellent SVR rates in Mexican patients who had not 57 responded to PegIFNa2a+RBV therapy. Improvement in CPS, FIB-4 and APRI without 58 improvement in fibrosis was observed in cirrhotic and non-cirrhotic patients, as well as 59 considerable reduction in liver transaminases, which suggests a reduction in hepatic 60 necroinflammation.

61

\section{Introduction}

63 In 2015, the World Health Organization (WHO) estimated 1.75 million new hepatitis C virus 64 (HCV) infections and that 71 million people in the world were living with chronic hepatitis $\mathrm{C}$ 65 (CHC). Approximately 400,000 people died from CHC related liver diseases mainly cirrhosis 66 and hepatocellular carcinoma (HCC) in that year (World Health Organization, 2017).

\section{For nearly a decade, the first-line therapy against $\mathrm{CHC}$ was pegylated interferon alpha}

8 (pegIFN $\alpha$ ) with ribavirin (RBV), but sustained virological response (SVR) was observed only in $40-50 \%$ of patients infected with viral genotype 1 and in $70 \%$ of those with genotypes 2 or 3

(Hofmann et al., 2015). In the last five years, the direct-acting antiviral agents (DAAs), have revolutionized CHC treatment (Elbaz et al., 2015). The first generation DAAs (boceprevir and 2 telaprevir) were serine protease inhibitors used in triple combination with interferon and RBV 3 that had low tolerability (Watanabe et al., 2016). New DAA combinations without interferon 74 (i.e. sofosbuvir, simeprevir and ombitasvir), that target several viral-cycle proteins, like NS3/4A (protease), NS5A and NS5B (RNA polymerase), were introduced in 2013-2014 and show enhanced efficacy and tolerability. These second generation DAAs, have increased SVR rates to over $90 \%$ and effectively treat all HCV genotypes (Gotte \& Feld, 2016) even in patients with advanced cirrhosis (Mizokami et al., 2015), making them efficient curative therapies. However, access to DAAs varies greatly among countries. According to WHO, only around half of patients with CHC that started treatment in 2015 received DAAs, and they concentrated in high income countries (World Health Organization, 2017). Thus, data on real-world safety and effectiveness of DAA regimens are still emerging for the middle- and low-income countries that harbor most 
83 of the CHC patients. There is limited data on real-world DAA treatments administered through 84 public health systems in Latin America (LA), which are crucial in the efforts to eradicate HCV. 85 Delivering DAA treatments to patients in need is now a main challenge worldwide. The high 86 costs of DAA regimens are restrictive even for patients in high-income countries. This results in 87 a portion of patients being treated only after liver fibrosis/cirrhosis have emerged, and highlights 88 the need to understand the effects of DAAs on liver fibrosis and inflammation.

89 In Mexico the most frequent HCV genotype is 1. Treatment for this genotype with 90 pegIFN $\alpha+$ RBV has a low SVR rate of around 38\% (Sandoval-Ramirez et al., 2015), while the 91 SVR with DAAs has not been reported in this country and few reports exist for LA (Cheinquer 92 et al., 2017). Large public health systems such as the Mexican Institute of Social Security

Social, 2018), introduced DAA regimens in 2017, initially treating patients who received and did not respond to pegIFNa2a+RBV. We studied Mexican adults with $\mathrm{CHC}$ that were treated with pegIFN $\alpha 2 a+$ RBV between 2005 and 2014. The non-responders from that cohort were among the first treated with DAAs in a real-world, public health setting in Mexico between 2017 and 2019 and their results are reported here.

\section{Materials \& Methods}

\section{Study Design}

We conducted a descriptive, ambispective and longitudinal study in two treatment phases for patients with chronic $\mathrm{HCV}$ infection on a cohort of patients who initially received pegIFN $\alpha 2 a+R B V$ treatment before 2014; non-responding patients were subsequently treated with DAAs. Tolerability, safety and effectiveness were analyzed.

\section{Initial cohort with pegIFN $2 a+R B V$ treatment (2005 to 2014)}

The cohort study was carried out with 261 patients at a High Specialty Medical Unit of the Mexican Institute of Social Security (UMAE-HE, IMSS) in the city of Puebla, Mexico. All patients were 18 years old or over, with CHC, infected by HCV genotype 1 (1a, 1b, 1a1b), without cirrhosis or with compensated cirrhosis.

\section{$H C V$ genotype and viral load in the initial cohort}

The viral genotype was determined with INNO-LiPA HCV II (Inogenetics, Zwijnarde, Belgium), and the viral load with AmpliPrep/Cobas and AmpliPrep/Cobas TaqMan HCV test (Roche Molecular Systems, Indianapolis, IN, USA), before treatment and at 4, 12, 24, 48 and 72 weeks after the start of pegIFN $\alpha+\mathrm{RBV}$.

\section{PegIFNa2a+RBV Treatment}

Patients received standard therapy for 48 weeks with pegIFN $\alpha 2 \mathrm{a} 180 \mu \mathrm{g} /$ week plus ribavirin, at a dose adjusted by body weight in the range of 1000-1200 mg/day. Rapid virological response (RVR, defined as undetectable HCV RNA after 4 weeks of treatment), complete early 
124 virological response (cEVR, undetectable HCV RNA after 12 weeks of treatment), partial early 125 virological response (pEVR, a $\geq 2-\log 10$ decrease in HCV RNA after 12 weeks of treatment), 126 slow virological response (SLVR, a $\geq 2-\log 10$ decrease in HCV RNA after 12 weeks and 127 undetectable after 24 weeks of treatment), null response (decrease in HCV RNA $<2$ logs at week 128 12), SVR (absence of detectable HCV-RNA at 24 weeks after the end of treatment), relapse (HCV-RNA became undetectable during treatment but reappeared after treatment

131

132

133

134

135

136

137

138

139

140

141

142

143

144

145

146

147

148

149

150

151

152

153

154

155

156

157

158

159

160

161

162

163

164

165

discontinuation), breakthrough (detection of $\mathrm{HCV}$ RNA at any point during treatment after dropping to undetectable levels or an increase $>1 \log$ compared to the nadir); non-responder (NR) includes null response, relapse and breakthrough patients, to pegIFNa2a+RBV were determined according to the Mexican consensus on the diagnosis and management of hepatitis $\mathrm{C}$ infection (Sanchez-Avila et al., 2015).

\section{Sub-cohort of non-responder patients to pegIFN $2 a+R B V$ that underwent DAA treatment in} 2017 to 2019

A sub-cohort of patients classified as NR to pegIFNa2a+RBV that returned for, and completed, DAA treatment between June 2017 and January 2019 was studied. These patients were candidates for DAA treatment irrespective of their cirrhosis degree.

\section{Laboratory and imaging tests in the sub-cohort with DAA treatment}

Cirrhosis was diagnosed with clinical, and laboratory data, plus hepatic elastography and ultrasound. A single hepatic elastography performed pre-treatment (FibroScan 530 Compact, Echosens, France) was used to determine steatosis, and METAVIR score of Fibrosis. Serum determinations of total bilirubin, albumin, International Normalization Ratio of prothrombin time (INR), aspartate aminotransferase (AST), alanine aminotransferase (ALT), platelet counts (PC), the presence of ascites, or hepatic encephalopathy, Child-Pugh-Score (CPS), Fibrosis-4 (FIB-4), and AST to Platelet Ratio Index (APRI) were evaluated before and after treatment.

Confirmation of the viral genotype, and HCV RNA viral load determinations were done with the Real Time System HCV Assay (Abbott Molecular, Abbott Park, Illinois USA). The lower limit of quantification (LLOQ) is $1.39 \log _{10} \mathrm{IU} / \mathrm{mL}$, and lower limit of detection (LLOD) is 1.08 $\log _{10} \mathrm{IU} / \mathrm{ml}$. The viral load was measured at DAA treatment start, at 12 weeks (treatment end) and at 24 weeks (12 weeks after treatment end).

\section{Treatment with $O B V / P T V / r / D S V \pm R B V$ or $S O F / L D V \pm R B V$}

Patients were evaluated by the group of experts in the management of hepatitis C (GEMHEC) at IMSS, who determined which of two available DAA regimens was best for each patient, based on medical criteria: Patients without cirrhosis, or with cirrhosis CPS-A to CPS-B, were treated with $O B V / P T V / r / D S V \pm R B V$ at 25/150/100/500 $\pm 1000-1200 \mathrm{mg}$ per day, for 12 weeks. Patients, without cirrhosis, or with cirrhosis CPS-A to CPS-C, were treated with $S O F / L D V \pm R B V$ at 400/90 $\pm 1000-1200 \mathrm{mg}$ per day, for 12 weeks. Patients with decompensated cirrhosis received $\mathrm{RBV}$ in their treatment regimen. The effectiveness of each regime was assessed by the percentage of patients with SVR12 defined as undetectable plasma HCV RNA 12 weeks after treatment end. 
166

167

168

169

170

171

172

173

174

175

176

177

178

179

180

181

182

183

184

185

186

187

188

189

190

191

192

193

194

195

196

197

198

199

200

201

202

203

204

205

\section{Ethical aspects}

The study was performed in accordance with ethical regulations and approved by the committee of research and ethics (Local Committee for Health Research No. 2101), IMSS (Registry numbers R-2004-2101-008, R-2008-2101-10, and R-2019-2101-001). Written informed consent was obtained from all patients prior to entering the study.

\section{Statistical analysis}

For quantitative variables, means $(95 \% \mathrm{CI})$, paired and unpaired Student's t test were calculated. For qualitative variables, frequencies, percentages, univariate analysis with chi-square or Fisher's exact tests, and multivariate analysis with multinomial logistic regression, were performed.

Statistical significance was defined as $p \leq 0.05$. All statistical analyses were done with GraphPad Prism version 5.0 (GraphPad software, Inc. San Diego CA).

\section{Results}

\section{Response to pegIFN $22 a+R B V$ treatment}

We analyzed the response of 261 Mexican adults with CHC and viral genotype 1, with or without cirrhosis, who received treatment with pegIFNa2a+RBV between 2005 to 2014 (patients characteristics in Table 1). 36\% of patients (94) achieved SVR, while 64\% (167) were nonresponders (Table 2).

Two independent variables were associated significantly with SVR after pegIFN $\alpha 2 \mathrm{a}+\mathrm{RBV}$ treatment in a multivariate analysis: not having cirrhosis $(\mathrm{RR}=3.0)$ and having a baseline viral load $<5.69 \log _{10} \mathrm{IU} / \mathrm{ml}(\mathrm{RR}=3.5)$; the opposite conditions were associated to null response (Table $3)$.

pEVR was associated to SVR, but the other intermediate responses (RVR and cEVR) were ambivalently associated with SVR and relapse at the same time during pegIFNa2a+RBV treatment, so we do not consider their association to be relevant for this study (Table 3). All of the non-responders to pegIFNa2a+RBV that were alive in 2017 were invited to receive DAA treatment and 83 patients attended. The rest ( 84 patients) did not receive subsequent DAA treatment through IMSS: 13 had died before 2015 and the rest were unavailable for follow-up.

The baseline characteristics of the patients that received and did not receive DAAs are contrasted in Table S1.

\section{Sub-cohort of non-responders to pegIFN $\alpha 2 a+R B V$ that received $D A A$ treatment} Of the 83 patients that returned for DAA treatment, 31 received $O B V / P T V / r / D S V$ and 8 $O B V / P T V / r / D S V \pm R B V$, while 35 received $S O F / L D V \pm R B V$ and $9 S O F / L D V$, for 12 weeks. Demographic data, comorbidities, type of response to the previous treatment, steatosis grade, and basal platelet counts, were similar between the two groups (Table 4).

Viral genotype 1a predominated in the $S O F / L D V \pm R B V$ group. This group also had a lower viral load and a higher proportion of patients with cirrhosis pre-DAA treatment than the 
206

207

208

209

210

211

212

213

214

215

216

217

218

219

220

221

222

223

224

225

226

227

228

229

230

231

232

233

234

235

236

237

238

239

240

241

242

243

244

245

$O B V / P T V / r / D S V \pm R B V$ group (Table 4). An overall SVR rate of $97.6 \%$ was obtained at 24 weeks (12 weeks after treatment end) in 83 patients who had either of the DAA treatments, with no significant difference in SVR between treatments $(p=0.217)$ (Table 2).

Two patients, both treated with $O B V / P T V / r / D S V \pm R B V$, had non-response: 1 had null response, and 1 had relapse. Both patients were men, without comorbidities, and had an initial viral load $>5.58 \log _{10} \mathrm{UI} / \mathrm{ml}$ (Table 5). No demographic, clinical, or laboratory characteristics were significantly associated with non-response (Table S2).

At week 12 (end of treatment), 5 patients treated with OBV/PT/r/DSV \pm RBV and 3 patients with $\mathrm{SOF} / \mathrm{LDV} \pm \mathrm{RBV}$ still had detectable viral RNA (above LLOD but, below LLOQ). Twelve weeks after the end of treatment, 7 of these patients had undetectable viral RNA, while the last patient (treated with OBV/PTV/r/DSV+RBV) attianed undetectable viral RNA at week 24 after the end of treatment. Therefore, all 8 patients eventually achieved SVR with the DAAs. Table 5 shows their characteristics.

\section{Child-Pugh Score, serological fibrosis markers FIB-4 and APRI before and after DAA} treatments

CPS post-treatment improved significantly in 12 patients with cirrhosis. After $\mathrm{OBV} / \mathrm{PTV} / \mathrm{r} / \mathrm{DSV} \pm \mathrm{RBV}$ treatment, 1 patient improved from CPS-B to -A; while after $\mathrm{SOF} / \mathrm{LDV} \pm \mathrm{RBV}$ treatment, 11 patients improved: one from CPS-C to $-\mathrm{A}$, and the other 10 from CPS-B to -A (Table 6).

Since hepatic elastography was carried out only pre-treatment we did not have a direct METAVIR comparison of the hepatic fibrosis before and after DAAs. Therefore, we determined the FIB-4 score, and the APRI index, to explore whether liver fibrosis changed with treatment. We found a decrease in mean FIB-4 and APRI values with both DAA regimens that was observed in both cirrhotic and non-cirrhotic patients. This decrease was enough to rate below the threshold for $\mathrm{F} 4$ cirrhosis in patients after $O B V / P T V / r / D S U \pm R B V$ but not after $S O F / L D V \pm R B V$, which had more F4 cirrhosis before treatment. Non-cirrhotic patients still rated as having persistent liver fibrosis after DAAs, despite the decrease in mean FIB-4 and APRI values (Table $6)$.

\section{Tolerability and adverse events to DAAs}

The adverse effects during DAA treatments were epigastralgia (18\%), headache $(12 \%)$, hyperbilirubinemia without elevation of ALT or AST during the first two weeks $(12 \%)$, fever $(2.4 \%)$, and pruritus (1.2\%). All the events were tolerated and controllable and none of the patients discontinued treatment. One patient, treated with $S O F / L D V \pm R B V$, had a sudden hepatic decompensation, that could be associated with frequent ingestion of Peumus boldus leave infusions during treatment. Herb-drug interactions have been documented for P. boldus with other drugs (Awortwe et al., 2018). The patient discontinued the infusions, corrected the hepatic decompensation, completed treatment and reached SVR. 


\section{Discussion}

247 SVR is attained only in about half of CHC patients treated with pegIFN $\alpha+$ RBV but in over $90 \%$

248 of those treated with DAAs. Widespread access to DAAs was initially delayed by drug costs and 249 accessibility, especially in some world regions that harbor most of the CHC patients (World

250 Health Organization, 2017). The switch to the new treatments in those regions has been slow

251

252

253

254

255

256

257

258

259

260

261

262

263

264

265

266

267

268

269

270

271

272

273

274

275

276

277

278

279

280

281

282

283

284

285 and relies importantly on public health systems. Mexico and Brazil are the countries in Latin America with the highest rates of cirrhosis, related to alcoholism and CHC (Mendez-Sanchez et al., 2018). Mexican public health institutions, such as IMSS, included DAAs in their list of essential medicines in June 2017, initially treating patients who had failed pegIFNa2a+RBV. This is the first report of the outcome of a Mexican cohort treated this way and followed longterm.

We found $36 \%$ SVR with the initial pegIFNa2a+RBV regimen (Table 2), similar to previous reports in Mexico of 32.5\% (Sandoval-Ramirez et al., 2015). Fifty one percent of the noncirrhotic patients, and $68 \%$ of those with low baseline viral load achieved SVR with pegIFNa2a+RBV (Table 3), similar to other publications (Enomoto \& Nishiguchi, 2015; Naing et al., 2015). Diabetes did not associate with failure of pegIFNa2a+RBV treatment: $34.2 \%$ of diabetic patients achieved SVR (Table 3), similar to SVR of all the cohort. The original cohort included equivalent amounts of patients with HCV subtypes $1 \mathrm{a}$ and $1 \mathrm{~b}$ (Table 1), which had similar SVR rates with pegIFNa2a+RBV (Table 2).

Not all patients that displayed some initial response to pegIFN $\alpha 2 \mathrm{a}+\mathrm{RBV}$ (RVR, cEVR or pEVR) achieved SVR: $14.6 \%$ (38/261) relapsed (Table S1), comparable to previous reports of $16 \%$ and $14.4 \%$ relapse $(15,17)$. Thus, RVR, cEVR, pEVR were not predictors of SVR or relapse with pegIFNa2a+RBV (Table 3). The low SVR rate with this treatment was likely associated to the high frequency of cirrhosis and the high viral load present in our initial cohort (Table 1). This was expected, as virus elimination is difficult with pegIFN $\alpha 2 \mathrm{a}+\mathrm{RBV}$ when the viral load is high, in particular for genotype 1 (Enomoto \& Nishiguchi, 2015).

Of the 167 non-responder patients to pegIFNa2a+RBV, only 83 returned for DAA treatment and all of them concluded therapy with either $O B V / P T V / r / D S V \pm R B V$ or $S O F / L D V \pm R B V$. DAA treatment happened on average 7 years after pegIFN $\alpha 2 \mathrm{a}+\mathrm{RBV}$ treatment, thus the sub-cohort with DAA treatment was older (56.2 vs 49.5 years), had a higher cirrhosis rate (60\% vs 29\%) and a lower basal average viral load, when they received DAAs than at pegIFNa2a+RBV treatment. Women were $74.6 \%$ of the patients treated with DAAs, which is a high percentage compared to other DAA real-world studies that report 35\% (Perello et al., 2017), 45\% (Flisiak et al., 2016) 54\% (Mendizabal et al., 2017), and 44.4\% (Holzmann et al., 2018) females (the last two in Latin America). The high proportion of women in our cohort likely reflects that in Mexico an important risk factor for $\mathrm{CHC}$ is the history of blood transfusion prior to 1995 (Lopez-Colombo et al., 2014) likely during obstetric or gynecological procedures. Females had a higher mean age than men in our DAA sub-cohort (Table 4).

SVR in the group treated with $O B V / P T V / r / D S V \pm R B V$ was $94.8 \%$, similar to other studies that have reported 96\% (Welzel et al., 2017), 99\% (MALACHITE II trial) (Dore et al., 2016), and 
286

287

288

289

290

291

292

293

294

295

296

297

298

299

300

301

302

303

304

305

306

307

308

309

310

311

312

313

314

315

316

317

318

319

320

321

322

323

324

325

98.7\% (AMBER study) (Flisiak et al., 2016), in patients with previous treatment; or 96.8\% (Mendizabal et al., 2017) and 96.2\% (Perello et al., 2017) including both treatment-naïve and previously treated patients respectively. Two patients presented failure to $O B V / P T V / r / D S V \pm R B V$, that did not associate with any of the studied factors (Table S2), similar to previous reports (Flisiak et al., 2016). However non-responders were 2/10 men in contrast to 0/29 women, and $2 / 21$ patients without cirrhosis, in contrast to $0 / 18$ patients with cirrhosis (Table S2).

SVR in the group treated with $S O F / L D V \pm R B V$ was $100 \%$, similar to two multicenter studies that have reported $95.8 \%$, and 92.5 to $100 \%$, respectively (Calleja et al., 2017; Terrault et al., 2016) in patients with previous treatment; $99 \%$ in cirrhotic patients with viral subtype 1b (Ogawa et al., 2017), and a meta-analysis reported $\geq 95 \%$ (Rezaee-Zavareh et al., 2017). Our SOF/LDV $\pm R B V$ group had $72.7 \%$ of cirrhotic patients and viral subtype 1a predominated over $1 \mathrm{~b}$ (Table 2). Male gender (Ogawa et al., 2017), basal albumin $<3.5 \mathrm{~g} / \mathrm{dL}$, and basal total bilirubin $>2.0 \mathrm{mg} / \mathrm{dL}$ have been associated with failure to $S O F / L D V \pm R B V$ treatment (Calleja et al., 2017; Terrault et al., 2016). In contrast, in our study $75 \%$ of patients with $S O F / L D V \pm R B V$ were women; $47.8 \%$ had basal albumin $>3.5 \mathrm{~g} / \mathrm{dL}$ and $68 \%$ had basal total bilirubin $<2.0 \mathrm{mg} / \mathrm{dL}$, likely favoring SVR (Table 4).

Biochemical improvement was observed after both DAA treatments, particularly $10 \%$ increase in albumin levels, up to 3-fold decrease in ALT and AST levels, and no decrease in hemoglobin despite $79 \%$ of patients with SOF/LDV receiving RBV. In agreement with lack of change in hemoglobin, indirect bilirubin did not increase with DAAs either (Table 6). An AFP concentration above $10 \mathrm{ng} / \mathrm{mL}$ was found in $28.9 \%$ of patients pretreatment and the concentrations decreased by $50 \%$ after DAA treatment (Table 5). Only one patient (4.16\%) showed an increase in AFP levels after treatment, in contrast to $22.9 \%$ found in another study (Fouad et al., 2019). Biochemical improvement translated into better CPS: 12 cirrhotic patients improved the CPS post-DAAs (Table 5). Other studies report changes in CPS at 36 weeks (ElSherif et al., 2018), and at 6 months (Essa et al., 2019) post DAAs.

Ninety eight percent of our patients eradicated HCV after 12 weeks of treatment, but we detected residual HCV RNA at treatment end (12 weeks), in 8 patients that became undetectable in the following months (Table S2), A study reported that normalization of albumin, AST, and ALT levels after DAA treatment is associated with the restoration of immune activity (Kostadinova et al., 2018), suggesting that the immune response may clear the residual virus in the following weeks.

Still, not all patients showed biochemical improvement. For example, elevated ALT persisted post-treatment in $8(9.8 \%)$ of patients, corresponding to patients with cirrhosis. This suggests the persistence of chronic liver inflammation despite SVR with DAAs in some cirrhotic patients, as has been observed (Enomoto et al., 2018).

The serological fibrosis markers FIB-4 and APRI showed a significant decrease after DAA treatment $(\mathrm{p}<0.05)$ (Table 5). However, their values suggest that cirrhosis and liver fibrosis were not eliminated by DAA treatments (Table 5). A recent study with non-cirrhotic patients reported that APRI and FIB-4 rates decrease rapidly and steadily from week 2 to week 12 post-DAA 
326

327

328

329

330

331

332

333

334

335

336

337

338

339

340

341

342

343

344

345

346

347

348

349

350

351

352

353

354

355

356

357

358

359

360

361

362

363

364

365

treatment (Hsu et al., 2019). Another study reported a decrease in transient elastography 18 months after treatment, but the authors discuss that it remains to be examined whether this indicates a true regression of fibrosis or simply the resolution of chronic liver inflammation (Bachofner et al., 2017). A study with liver biopsies of patients that reached SVR, reported a decrease in the Knodell inflammatory score, and did not observe short-term improvement in fibrosis post-DAA treatment (41 \pm 20 weeks after treatment end) (Enomoto et al., 2018). Thus, our observation on FIB-4 and APRI decrease wit treatment, could be due more to an improvement in chronic liver inflammation, which is supported by the significant decrease in liver transaminases (Table 5).

The biochemical and hepatic-fibrosis characterization of patients treated with DAAs, is instrumental to understand details beyond SVR, in particular related to liver inflammation and its contribution to long-term outcomes, like HCC. Several studies report that patients with cirrhosis remain at risk of HCC despite SVR, irrespective of the treatment (even with DAAs) (ChinchillaLopez et al., 2017; Waziry et al., 2017). In contrast, in patients without cirrhosis, a decrease in liver inflammation reduces the risk of cirrhosis and HCC (Hsu et al., 2019). This suggests that the best window for DAA treatment is before the onset of cirrhosis.

\section{Conclusions}

DAA treatment showed good tolerability and safety, as well as excellent SVR rates in Mexican patients who had been unsuccessfully treated with pegIFNa2a+RBV several years earlier. ChildPugh-Score improved in some patients with cirrhosis. Treatment with DAA did not correct cirrhosis, but FIB-4 and APRI suggest a reduction in chronic liver inflammation.

\section{Acknowledgements}

JRL has a research fellowship from Fundación IMSS A.C., Mexico

(www.fundacionimss.org.mx).

\section{Funding}

Costs of medical attention and diagnosis were covered by Instituto Mexicano del Seguro Social. There was no additional external funding received for this study.

\section{Author Contributions}

DMM, MAMT, VSM, PCH, JRL, GSL and FSJ conceived and designed the study; DMM, MAMT, VGG, ERG, MBD, BGF, JCE, IGS, JCFA and VVR cared for patients and performed laboratory tests; VSM, VGG, YML, VVR, PCH, GSL and FSJ analyzed the data; DMM, VSM, VVR, PCH, JRL, GSL and FSJ prepared the tables; DMM, VSM, VVR, PCH, JRL, GSL and FSJ drafted the work or revised it critically for important content. 


\section{References}

368

369

370

371

372

373

374

375

376

377

378

379

380

381

382

383

384

385

386

387

388

389

390

391

392

393

394

395

396

397

398

399

400

401

402

403

404

405

406

407

408

409

410

411

Awortwe C, Makiwane M, Reuter H, Muller C, Louw J, and Rosenkranz B. 2018. Critical evaluation of causality assessment of herb-drug interactions in patients. Br J Clin Pharmacol 84:679-693. 10.1111/bcp.13490

Bachofner JA, Valli PV, Kroger A, Bergamin I, Kunzler P, Baserga A, Braun D, Seifert B, Moncsek A, Fehr J, Semela D, Magenta L, Mullhaupt B, Terziroli Beretta-Piccoli B, and Mertens JC. 2017. Direct antiviral agent treatment of chronic hepatitis $C$ results in rapid regression of transient elastography and fibrosis markers fibrosis-4 score and aspartate aminotransferase-platelet ratio index. Liver Int 37:369-376. 10.1111/liv.13256

Calleja JL, Crespo J, Rincon D, Ruiz-Antoran B, Fernandez I, Perello C, Gea F, Lens S, Garcia-Samaniego J, Sacristan B, Garcia-Eliz M, Llerena S, Pascasio JM, Turnes J, Torras X, Morillas RM, Llaneras J, Serra MA, Diago M, Rodriguez CF, Ampuero J, Jorquera F, Simon MA, Arenas J, Navascues CA, Banares R, Munoz R, Albillos A, Marino Z, and Spanish Group for the Study of the Use of Direct-acting Drugs Hepatitis CCG. 2017. Effectiveness, safety and clinical outcomes of direct-acting antiviral therapy in HCV genotype 1 infection: Results from a Spanish real-world cohort. J Hepatol 66:1138-1148. 10.1016/j.jhep.2017.01.028

Cheinquer H, Sette H, Jr., Wolff FH, de Araujo A, Coelho-Borges S, Soares SRP, and Barros MFA. 2017. Treatment of Chronic HCV Infection with the New Direct Acting Antivirals (DAA): First Report of a Real World Experience in Southern Brazil. Ann Hepatol 16:727-733. 10.5604/01.3001.0010.2717

Chinchilla-Lopez P, Qi X, Yoshida EM, and Mendez-Sanchez N. 2017. The Direct-Acting Antivirals for Hepatitis C Virus and the Risk for Hepatocellular Carcinoma. Ann Hepatol 16:328-330. 10.5604/16652681.1235473

Dore GJ, Conway B, Luo Y, Janczewska E, Knysz B, Liu Y, Streinu-Cercel A, Caruntu FA, Curescu M, Skoien R, Ghesquiere W, Mazur W, Soza A, Fuster F, Greenbloom S, Motoc A, Arama V, Shaw D, Tornai I, Sasadeusz J, Dalgard O, Sullivan D, Liu X, Kapoor M, Campbell A, and Podsadecki T. 2016. Efficacy and safety of ombitasvir/paritaprevir/r and dasabuvir compared to IFN-containing regimens in genotype $1 \mathrm{HCV}$ patients: The MALACHITE-I/II trials. $J$ Hepatol 64:19-28. 10.1016/j.jhep.2015.08.015

El-Sherif O, Jiang ZG, Tapper EB, Huang KC, Zhong A, Osinusi A, Charlton M, Manns M, Afdhal NH, Mukamal K, McHutchison J, Brainard DM, Terrault N, and Curry MP. 2018. Baseline Factors Associated With Improvements in Decompensated Cirrhosis After Direct-Acting Antiviral Therapy for Hepatitis C Virus Infection. Gastroenterology 154:21112121 e2118. 10.1053/j.gastro.2018.03.022

Elbaz T, El-Kassas M, and Esmat G. 2015. New era for management of chronic hepatitis $\mathrm{C}$ virus using direct antiviral agents: A review. $J$ Adv Res 6:301-310. 10.1016/j.jare.2014.11.004

Enomoto H, and Nishiguchi S. 2015. Factors associated with the response to interferon-based antiviral therapies for chronic hepatitis C. World $J$ Hepatol 7:2681-2687. 10.4254/wjh.v7.i26.2681

Enomoto M, Ikura Y, Tamori A, Kozuka R, Motoyama H, Kawamura E, Hagihara A, Fujii H, Uchida-Kobayashi S, Morikawa H, Murakami Y, and Kawada N. 2018. Short-term histological evaluations after achieving a sustained virologic response to direct-acting antiviral treatment for chronic hepatitis C. United European Gastroenterol J 6:1391-1400. $10.1177 / 2050640618791053$

Peerj reviewing PDF | (2021:04:59862:1:1:NEW 9 Jul 2021) 
412 Essa M, Sabry A, Abdelsameea E, Tharwa ES, and Salama M. 2019. Impact of new direct-

413

414

415

416

417

418

419

420

421

422

423

424

425

426

427

428

429

430

431

432

433

434

435

436

437

438

439

440

441

442

443

444

445

446

447

448

449

450

451

452

453

454

455

456 acting antiviral drugs on hepatitis $\mathrm{C}$ virus-related decompensated liver cirrhosis. Eur $J$ Gastroenterol Hepatol 31:53-58. 10.1097/MEG.0000000000001250

Flisiak R, Janczewska E, Wawrzynowicz-Syczewska M, Jaroszewicz J, Zarebska-Michaluk D, Nazzal K, Bolewska B, Bialkowska J, Berak H, Fleischer-Stepniewska K, Tomasiewicz K, Karwowska K, Rostkowska K, Piekarska A, Tronina O, Madej G, Garlicki A, Lucejko M, Pisula A, Karpinska E, Kryczka W, Wiercinska-Drapalo A, Mozer-Lisewska I, Jablkowski M, Horban A, Knysz B, Tudrujek M, Halota W, and Simon K. 2016. Realworld effectiveness and safety of ombitasvir/paritaprevir/ritonavir +/- dasabuvir +/- ribavirin in hepatitis C: AMBER study. Aliment Pharmacol Ther 44:946-956. 10.1111/apt.13790

Fouad R, Elsharkawy A, Abdel Alem S, El Kassas M, Alboraie M, Sweedy A, Afify S, Abdellatif Z, Khairy M, and Esmat G. 2019. Clinical impact of serum alpha-fetoprotein and its relation on changes in liver fibrosis in hepatitis $\mathrm{C}$ virus patients receiving direct-acting antivirals. Eur J Gastroenterol Hepatol 31:1129-1134. 10.1097/MEG.0000000000001400

Gotte M, and Feld JJ. 2016. Direct-acting antiviral agents for hepatitis C: structural and mechanistic insights. Nat Rev Gastroenterol Hepatol 13:338-351. 10.1038/nrgastro.2016.60

Hofmann WP, Mauss S, Lutz T, Schober A, Boker K, Moog G, Baumgarten A, PfeifferVornkahl H, Alshuth U, Huppe D, Wedemeyer H, Manns MP, and Schott E. 2015. Benefit of Treatment Individualization in Patients with Chronic Hepatitis C Receiving Peginterferon Alfa-2a and Ribavirin in a Large Noninterventional Cohort Study. PLoS One 10:e134839. 10.1371/journal.pone.0134839

Holzmann I, Tovo CV, Minme R, Leal MP, Kliemann MP, Ubirajara C, Aquino AA, Araujo B, and Almeida PRL. 2018. Effectiveness of chronic hepatitis $C$ treatment with direct-acting antivirals in the Public Health System in Brazil. Braz J Infect Dis 22:317-322. 10.1016/j.bjid.2018.06.004

Hsu WF, Lai HC, Su WP, Lin CH, Chuang PH, Chen SH, Chen HY, Wang HW, Huang GT, and Peng CY. 2019. Rapid decline of noninvasive fibrosis index values in patients with hepatitis $\mathrm{C}$ receiving treatment with direct-acting antiviral agents. BMC Gastroenterol 19:63. 10.1186/s 12876-019-0973-5

Instituto Mexicano del Seguro Social. 2018. Informe al Ejecutivo Federal y al Congreso de la Unión sobre la situación financiera y los riesgos del Instituto Mexicano del Seguro Social 2017-2018. CIudad de México, México: Instituto Mexicano del Seguro Social.

Kostadinova L, Shive CL, Zebrowski E, Fuller B, Rife K, Hirsch A, Compan A, Moreland A, Falck-Ytter Y, Popkin DL, and Anthony DD. 2018. Soluble Markers of Immune Activation Differentially Normalize and Selectively Associate with Improvement in AST, ALT, Albumin, and Transient Elastography During IFN-Free HCV Therapy. Pathog Immun 3:149-163. 10.20411/pai.v3i1.242

Lopez-Colombo A, Melendez-Mena D, Sedeno-Monge V, Camacho-Hernandez JR, Vazquez-Cruz E, Morales-Hernandez ER, Sosa-Jurado F, Marquez-Dominguez L, and Santos-Lopez G. 2014. Hepatitis $C$ virus infection in patients and family members attending two primary care clinics in Puebla, Mexico. Ann Hepatol 13:746-752.

Mendez-Sanchez N, Zamarripa-Dorsey F, Panduro A, Puron-Gonzalez E, CoronadoAlejandro EU, Cortez-Hernandez CA, Higuera de la Tijera F, Perez-Hernandez JL, Cerda-Reyes E, Rodriguez-Hernandez H, Cruz-Ramon VC, Ramirez-Perez OL, Aguilar-Olivos NE, Rodriguez-Martinez OF, Cabrera-Palma S, and Cabrera-Alvarez G.

Peer) reviewing PDF | (2021:04:59862:1:1:NEW 9 Jul 2021) 
2018. Current trends of liver cirrhosis in Mexico: Similitudes and differences with other world regions. World J Clin Cases 6:922-930. 10.12998/wjcc.v6.i15.922

Mendizabal M, Haddad L, Gallardo PE, Ferrada A, Soza AA, Adrover R, Aravena E, Roblero JP, Prieto J, Vujacich C, Romero G, Munoz A, Anders M, Hernandez N, Coccozella D, Gruz F, Reggiardo MV, Ruf AE, Varon A, Cartier M, Perez Ravier R, Ridruejo E, Peralta M, Poncino D, Vorobioff J, Aballay Soteras G, and Silva MO. 2017. Ombitasvir/paritaprevir/ritonavir/dasabuvir +/- ribavirin is safe and effective in HCV-infected patients in a real-life cohort from Latin America. J Med Virol 89:1590-1596. 10.1002/jmv.24816

Mizokami M, Yokosuka O, Takehara T, Sakamoto N, Korenaga M, Mochizuki H, Nakane K, Enomoto H, Ikeda F, Yanase M, Toyoda H, Genda T, Umemura T, Yatsuhashi H, Ide T, Toda N, Nirei K, Ueno Y, Nishigaki Y, Betular J, Gao B, Ishizaki A, Omote M, Mo H, Garrison K, Pang PS, Knox SJ, Symonds WT, McHutchison JG, Izumi N, and Omata M. 2015. Ledipasvir and sofosbuvir fixed-dose combination with and without ribavirin for 12 weeks in treatment-naive and previously treated Japanese patients with genotype 1 hepatitis C: an open-label, randomised, phase 3 trial. Lancet Infect Dis 15:645-653. 10.1016/S14733099(15)70099-X

Naing C, Sitt T, Aung AT, and Aung K. 2015. Sustained Virologic Response to a Dual Peginterferon alfa-2a and Ribavirin in Treating Chronic hepatitis C Infection: A Retrospective Cohort Study. Medicine (Baltimore) 94:e1234. 10.1097/MD.0000000000001234

Ogawa E, Furusyo N, Nomura H, Dohmen K, Higashi N, Takahashi K, Kawano A, Azuma K, Satoh T, Nakamuta M, Koyanagi T, Kato M, Shimoda S, Kajiwara E, Hayashi J, and Kyushu University Liver Disease Study G. 2017. NS5A resistance-associated variants undermine the effectiveness of ledipasvir and sofosbuvir for cirrhotic patients infected with HCV genotype 1b. J Gastroenterol 52:845-854. 10.1007/s00535-016-1290-1

Perello C, Carrion JA, Ruiz-Antoran B, Crespo J, Turnes J, Llaneras J, Lens S, Delgado M, Garcia-Samaniego J, Garcia-Paredes F, Fernandez I, Morillas RM, Rincon D, Porres JC, Prieto M, Lazaro Rios M, Fernandez-Rodriguez C, Hermo JA, Rodriguez M, Herrero JI, Ruiz P, Fernandez JR, Macias M, Pascasio JM, Moreno JM, Serra MA, Arenas J, Real Y, Jorquera F, Calleja JL, and Spanish Collaborative Group for the Study of the Use of Hepatitis CD-AD. 2017. Effectiveness and safety of ombitasvir, paritaprevir, ritonavir +/- dasabuvir +/- ribavirin: An early access programme for Spanish patients with genotype 1/4 chronic hepatitis C virus infection. J Viral Hepat 24:226-237. 10.1111/jvh.12637

Rezaee-Zavareh MS, Hesamizadeh K, Behnava B, Alavian SM, Gholami-Fesharaki M, and Sharafi H. 2017. Combination of Ledipasvir and Sofosbuvir for Treatment of Hepatitis C Virus Genotype 1 Infection: Systematic Review and Meta-Analysis. Ann Hepatol 16:188-197. $10.5604 / 16652681.1231562$

Sanchez-Avila JF, Dehesa-Violante M, Mendez-Sanchez N, Bosques-Padilla F, CastilloBarradas M, Castro-Narro G, Cisneros-Garza L, Chirino-Sprung RA, Garcia-Juarez I, Gonzalez-Huezo MS, Male-Velazquez R, Moreno-Alcantar R, Munoz-Espinoza L, Ramos-Gomez M, Rizo-Robles MT, Sandoval-Salas R, Sierra-Madero J, Torres-Ibarra Mdel R, Vazquez-Frias R, Wolpert-Barraza E, Mexican Association of $H$, Mexican Association of G, and Mexican Hepatitis CCG. 2015. Mexican consensus on the diagnosis and management of hepatitis C infection. Ann Hepatol 14 Suppl 1:5-48. 
501

502

503

504

505

506

507

508

509

510

511

512

513

514

515

516

517

518

519

520

521

522

523

524

525

526
Sandoval-Ramirez JL, Mata-Marin JA, Huerta Garcia G, and Gaytan-Martinez JE. 2015. Responses to peginterferon alfa-2a vs alfa-2b plus ribavirin in a Mexican population with chronic hepatitis C. J Infect Dev Ctries 9:267-273. 10.3855/jidc.5284

Terrault NA, Zeuzem S, Di Bisceglie AM, Lim JK, Pockros PJ, Frazier LM, Kuo A, Lok AS, Shiffman ML, Ben Ari Z, Akushevich L, Vainorius M, Sulkowski MS, Fried MW, Nelson DR, and Group H-TS. 2016. Effectiveness of Ledipasvir-Sofosbuvir Combination in Patients With Hepatitis C Virus Infection and Factors Associated With Sustained Virologic Response. Gastroenterology 151:1131-1140 e1135. 10.1053/j.gastro.2016.08.004

Watanabe T, Joko K, Seike H, Michitaka K, Horiike N, Kisaka Y, Tanaka Y, Nakanishi S, Nakanishi K, Nonaka T, Yamauchi K, Onji M, Ohno Y, Tokumoto Y, Hirooka M, Abe M, and Hiasa Y. 2016. Simeprevir with peginterferon/ribavirin for patients with hepatitis C virus genotype 1: high frequency of viral relapse in elderly patients. Springerplus 5:518. 10.1186/s40064-016-2190-9

Waziry R, Hajarizadeh B, Grebely J, Amin J, Law M, Danta M, George J, and Dore GJ. 2017. Hepatocellular carcinoma risk following direct-acting antiviral HCV therapy: A systematic review, meta-analyses, and meta-regression. $J$ Hepatol 67:1204-1212. 10.1016/j.jhep.2017.07.025

Welzel TM, Hinrichsen H, Sarrazin C, Buggisch P, Baumgarten A, Christensen S, Berg T, Mauss S, Teuber G, Stein K, Deterding K, van Bommel F, Heyne R, John C, Zimmermann T, Lutz T, Schott E, Hettinger J, Kleine H, Konig B, Huppe D, and Wedemeyer H. 2017. Real-world experience with the all-oral, interferon-free regimen of ombitasvir/paritaprevir/ritonavir and dasabuvir for the treatment of chronic hepatitis $\mathrm{C}$ virus infection in the German Hepatitis C Registry. J Viral Hepat 24:840-849. 10.1111/jvh.12708

World Health Organization. 2017. Global Hepatitis Report, 2017. Geneva, Switzerland: World Health Organization. 


\section{Table $\mathbf{1}$ (on next page)}

Demographic and clinical characteristics of the cohort of 261 patients with $\mathrm{CHC}$, viral genotype 1, that received treatment with pegIFNa2a+RBV between 2005 and 2014. 
1 Table 1:

2 Demographic and clinical characteristics of the cohort of 261 patients with CHC, viral genotype

3 1, that received treatment with pegIFN $\alpha 2 a+R B V$ between 2005 and 2014.

\begin{tabular}{|c|c|}
\hline & $\mathrm{n}(\%)$ \\
\hline \multicolumn{2}{|l|}{$\operatorname{Sex}$} \\
\hline Women /Men & 165 / $96(63.2 / 36.7)$ \\
\hline \multicolumn{2}{|l|}{ Age } \\
\hline Range (years) & $15-73$ \\
\hline$<50($ year old $) / \geq 50$ (year old $)$ & $128 / 133(49 / 51)$ \\
\hline \multicolumn{2}{|l|}{ Mean age (years) $(95 \% \mathrm{CI})$} \\
\hline Women / Men & $50(48.5-52.4) / 45(42.8-47.4)$ \\
\hline \multicolumn{2}{|l|}{ Diagnosis } \\
\hline Non cirrhosis /Cirrhosis & 159 / $102(61 / 39)$ \\
\hline \multicolumn{2}{|l|}{ Comorbidity } \\
\hline Diabetes mellitus type 2 & $35(13.4)$ \\
\hline Hemophiliac & $3(1.14)$ \\
\hline HCC during study & $6(2.39)$ \\
\hline HIV & $2(0.76)$ \\
\hline $\mathrm{HBV}$ & $3(1.14)$ \\
\hline \multicolumn{2}{|l|}{ Viral genotypes } \\
\hline 1 (unsubtyped) & $10(3.8)$ \\
\hline $1 \mathrm{a}$ & $110(42.1)$ \\
\hline $1 b$ & $121(46.4)$ \\
\hline $1 \mathrm{alb}$ & $20(7.7)$ \\
\hline Total genotype 1 & $261(100.0)$ \\
\hline \multicolumn{2}{|l|}{ Basal viral load range $\left(\log _{10} I U / m l\right)$} \\
\hline Genotype 1 & $1.96-7.25$ \\
\hline \multicolumn{2}{|c|}{ Mean basal viral load $\left(\log _{10} I U / m l\right)(95 \%$ CI) } \\
\hline Genotype 1 & $5.59(5.50-5.68)$ \\
\hline
\end{tabular}

4 
Table 2 (on next page)

Final response to pegIFN $\alpha 2 a+R B V$ or DAA treatments. 
1 Table 2:

2 Final response to pegIFN $\alpha 2 \mathrm{a}+\mathrm{RBV}$ or DAA treatments.

PegIFNa2a+RBV treatment of 261 Mexican patients with $\mathrm{CHC}$ and viral genotype 1

Final Subtypes of Genotype 1

\begin{tabular}{lllll} 
response & $1+1 \mathrm{a} 1 \mathrm{~b}^{*}$ & $1 \mathrm{a}$ & $1 \mathrm{~b}$ & Total \\
\cline { 1 - 3 } NR, n $(\%)$ & $18(6.9)$ & $69(26.4)$ & $80(30.7)$ & $167(64)$ \\
SVR, n (\%) & $12(4.6)$ & $41(15.7)$ & $41(15.7)$ & $94(36)$ \\
Total & $30(11.5)$ & $110(42.1)$ & $121(46.4)$ & $261(100)$
\end{tabular}

DAA treatments in 83 previously treated Mexican patients with $\mathrm{CHC}$ and viral genotype 1

\begin{tabular}{llll}
\hline Regimen & SVR12, n $(\%)$ & NR12, n $(\%)$ & Total \\
\hline OBV/PTV/r/DSV+RBV & $7(87.5)$ & $1(12.5)$ & $8(100)$ \\
OBV/PTV/r/DSV & $30(96.8)$ & $1(3.2)$ & $31(100)$ \\
Total & $37(94.8)$ & $2(5.2)$ & $39(100)$ \\
\hline$S O F / L D V+R B V$ & $34(100.0)$ & $0(0.0)$ & $34(100.0)$ \\
$S O F / L D V$ & $10(100)$ & $0(0.0)$ & $10(100)$ \\
Total & $44(100)$ & $0(0.0)$ & $44(100)$
\end{tabular}

3 NR: Non-responder, SVR: sustained virological response, $p$ : value for Fisher's Exact test.

4 Statistical significance was defined as $\mathrm{p}<0.05$ (final response among genotypes). *Includes

5 patients with unsubtyped HCV genotype $1(n=10)$ and those detected as $1 \mathrm{a} 1 \mathrm{~b}(\mathrm{n}=20)$. SVR12:

6 sustained virological response for DAA treatments; NR12: Non-responder for DAA treatments. 


\section{Table 3(on next page)}

Multivariate analysis of factors that predisposed to sustained virological response, null response, or relapse with pegIFN $\alpha 2 a+R B V$ treatment, in a cohort of 261 Mexican patients with $\mathrm{CHC}$ and viral genotype 1 . 
1 Table 3.

2 Multivariate analysis of factors that predisposed to sustained virological response, null response,

3 or relapse with pegIFNa2a+RBV treatment, in a cohort of 261 Mexican patients with CHC and

4 viral genotype 1.

\begin{tabular}{lcccccc}
\hline \multicolumn{1}{c}{ Factor } & $\begin{array}{c}\text { SVR patients } \\
\text { RR }(95 \% \mathrm{CI})\end{array}$ & $p$ & $\mathrm{RR}(95 \% \mathrm{CI})$ & $p$ & $\mathrm{RR}(95 \% \mathrm{CI})$ & $p$ \\
\hline Sex & & & & & \\
Men & $1.1(0.8-1.5)$ & 0.592 & $0.9(0.7-1.3)$ & 0.797 & $07(0.4-1.3)$ & 0.328 \\
Women & & & & & & \\
Age (yr.) & & & & & & \\
$<50$ & $1.5(1.0-2.2)$ & 0.045 & $0.8(0.6-1.0)$ & 0.060 & $0.5(0.3-0.9)$ & 0.02 \\
$\geq 50$ & $1.3(1.0-1.9)$ & 0.066 & $0.70(0.4-$ & 0.044 & $0.5(0.3-0.9)$ & 0.05 \\
& & & $1.4)$ & & &
\end{tabular}

Diabetes mellitus

$\begin{array}{lllllll}\text { Yes } & 0.9(0.6-1.5) & 0.850 & 0.9(0.5-1.5) & 0.737 & 1.6(0.9-2.9) & 0.130\end{array}$

No

Liver disease

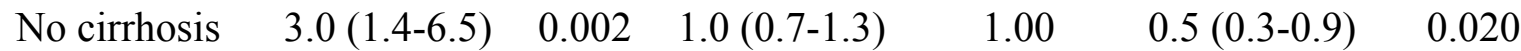

$\begin{array}{lllllll}\text { Cirrhosis } & 0.4(0.3-0.7) & 0.001 & 3.5(1.8-6.6) & <0.001 & 0.6(0.4-1.1) & 0.110\end{array}$

Initial Viral load $\left(\log _{10} \mathrm{IU} / \mathrm{ml}\right)$

$\begin{array}{ccccccc}<5.69 & 3.5(1.7-7.1) & 0.001 & 0.6(0.4-0.8) & 0.003 & 0.8(0.5-1.4) & 0.529 \\ \geq 5.69 & 0.58(0.43- & 0.001 & 2.4(1.3-4.3) & 0.005 & 1.8(0.9-3.8) & 0.090 \\ & 0.82 & & & & & \end{array}$

$R V R$

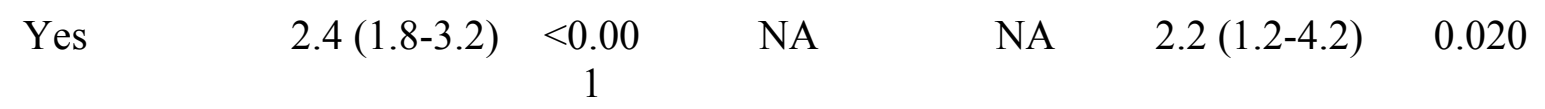

No

$c E V R$

$\begin{array}{llcllll}\text { Yes } & 2.2(1.6-2.9) & < & \text { NA } & \text { NA } & 5.0(2.8-9.0) & <0.001 \\ 0.001 & & & & & \end{array}$

No

$p E V R$

$\begin{array}{lllllll}\text { Yes } & 2.4(1.8-3.3) & 0.001 & \text { NA } & \text { NA } & 1.4(0.6-3.6) & 0.507\end{array}$

No

$5 \mathrm{NA}=$ does not apply. $*$ The mean viral load before pegIFN $\alpha 2 \mathrm{a}+\mathrm{RBV}$ was $5.69 \log _{10} \mathrm{IU} / \mathrm{ml} ; R V R=$

6 rapid virological response, $c E V R=$ complete early virological response, $p E V R=$ partial early

7 virological response. 


\section{Table 4 (on next page)}

Demographic and clinical data of the Mexican patients treated with $O B V / P T V / r / D S V \pm R B V$ or $S O F / L D V \pm R B V$. 
1 Table 4:

2 Demographic and clinical data of the Mexican patients treated with $O B V / P T V / r / D S V \pm R B V$ or

$3 S O F / L D V \pm R B V$.

\begin{tabular}{|c|c|c|c|}
\hline & $\begin{array}{l}\text { Patients treated with } \\
O B V / P T V / r / D S V \pm R B V(39)\end{array}$ & $\begin{array}{l}\text { Patients treated with } \\
S O F / L D V \pm R B V(44)\end{array}$ & $p$ \\
\hline \multicolumn{4}{|l|}{ Gender, $n(\%)$} \\
\hline Female/male & $29(74.3) / 10(25.7)$ & $33(75) / 11(25)$ & 0.182 \\
\hline Mean age $(95 \% \mathrm{CI})$ & $54.5(49-58)$ & $54.7(49.5-58)$ & \\
\hline Female/male age & $57.2(53-61) / 51.8(45-58)$ & $58.5(55-62) / 50(44-55)$ & $0.161 / 0.011$ \\
\hline \multicolumn{4}{|c|}{ Patients $\geq 50$ years old, $n(\%)$} \\
\hline All patients & $34(87.1)$ & $36(81.1)$ & 0.558 \\
\hline \multicolumn{4}{|c|}{ Response to pegIFN $2 a+R B V$ treatment, $n(\%)$} \\
\hline Null response & $27(69.3)$ & $29(65.9)$ & 0.816 \\
\hline Relapse & $9(23.0)$ & $14(31.8)$ & 0.461 \\
\hline Breakthrough & $3(7.7)$ & $1(2.3)$ & 0.337 \\
\hline Total & $39(100)$ & $44(100)$ & \\
\hline \multicolumn{4}{|l|}{ Comorbidity, $n(\%)$} \\
\hline Diabetes & $5(12.8)$ & $4(9.0)$ & 0.728 \\
\hline Smoking & $3(7.7)$ & $8(18.8)$ & 0.204 \\
\hline $\begin{array}{l}\text { Alcohol use } \\
\text { disorder }\end{array}$ & $5(12.8)$ & $3(6.8)$ & 0.465 \\
\hline Obesity * & $7(17.9)$ & $12(27.3)$ & 0.433 \\
\hline \multicolumn{4}{|c|}{ Viral Subtype 1, $n(\%)$} \\
\hline $1 \mathrm{a}$ & $8(21.5)$ & $34(77.3)$ & 0.024 \\
\hline $1 b$ & $31(79.5)$ & $10(22.7)$ & 0.024 \\
\hline Total & $39(100)$ & $44(100)$ & \\
\hline \multicolumn{4}{|c|}{ Initial viral load $\left(\log _{10} I U / m l\right)$} \\
\hline Mean $(\mathrm{CI} 95 \%)$ & $5.58(5.3-5.8)$ & $5.10(4.78-5.40)$ & 0.031 \\
\hline \multicolumn{4}{|c|}{ Initial viral load $>5.58\left(\log _{10} U I / m l\right), n(\%)$} \\
\hline Yes & $15(38.4)$ & $20(45.5)$ & 0.656 \\
\hline No & $24(61.6)$ & $24(54.5)$ & \\
\hline Total & $39(100)$ & $44(100)$ & \\
\hline \multicolumn{4}{|c|}{ METAVIR Score**, $n(\%)$} \\
\hline $\mathrm{F} 0$ or $\mathrm{F} 1$ & $17(43.6)$ & $8(18.2)$ & 0.01 \\
\hline
\end{tabular}




\begin{tabular}{|c|c|c|c|}
\hline $\mathrm{F} 2$ & $1(2.6)$ & $0(0.0)$ & 1.0 \\
\hline F3 & $3(7.7)$ & $4(9.0)$ & 1.0 \\
\hline F4 & $18(46.1)$ & $32(72.7)$ & $<0.001$ \\
\hline Total & $39(100)$ & $44(100.0)$ & \\
\hline \multicolumn{4}{|c|}{ Degree of steatosis ***, $n(\%)$} \\
\hline None & $16(41.0)$ & $21(47.8)$ & 0.658 \\
\hline 1 to 3 & $23(59.0)$ & $10(52.2)$ & 0.01 \\
\hline Total & 39 (100) & $44(100)$ & \\
\hline \multicolumn{4}{|c|}{ Basal albumin $>3.5 \mathrm{~g} / \mathrm{dL}, \mathrm{n}(\%)$} \\
\hline Yes & $31(79)$ & $21(47.8)$ & 0.003 \\
\hline No & $8(21)$ & $23(52.2)$ & \\
\hline Total & $39(100)$ & $44(100)$ & \\
\hline \multicolumn{4}{|c|}{ Basal total bilirubin $<2.0 \mathrm{mg} / \mathrm{dL}, n(\%)$} \\
\hline Yes & $35(89)$ & $30(68)$ & 0.03 \\
\hline No & $4(11)$ & $14(32)$ & \\
\hline Total & $39(100)$ & $44(100)$ & \\
\hline \multicolumn{4}{|c|}{ Basal platelet count $>100,000 /(\mathrm{mm} 3), n(\%)$} \\
\hline Yes & $28(72)$ & $23(52.2)$ & 0.001 \\
\hline No & $11(28)$ & $21(47.8)$ & \\
\hline Total & 39 (100) & 44 100) & \\
\hline
\end{tabular}

$4 *$ Body Mass Index (BMI) $\geq 30$, includes obesity degrees 1-3. **METAVIR Score from Hepatic 5 elastography (FibroScan) before DAA treatment, classified from the measurement in $\mathrm{kPa}$ :

$6<7.6 \mathrm{kPa}=\mathrm{F} 0-\mathrm{F} 1,7.7-9.4 \mathrm{kPa}=\mathrm{F} 2,9.5-12 \mathrm{kPa}=\mathrm{F} 3,>12 \mathrm{kPa}=\mathrm{F} 4$. $* * *$ Degree of steatosis

7 (FibroScan) $\leq 220 \mathrm{~dB} / \mathrm{m}=$ non steatosis, $>220-235 \mathrm{~dB} / \mathrm{m}=1,236-290 \mathrm{~dB} / \mathrm{m}=2,>290 \mathrm{~dB} / \mathrm{m}=3$. 8 


\section{Table 5 (on next page)}

Types of response and characteristics of the patients that either failed DAA-treatment (first two rows) or had detectable viral RNA at the end of DAA treatment (week 12) but finally were responders (week 24). 
Table 6:

2 Biochemical parameters and clinical data, pre-/post-DAA treatments.

\begin{tabular}{|c|c|c|c|c|c|c|}
\hline & \multicolumn{3}{|l|}{$\overline{O B V / P T V / r / D S V \pm R B V}$} & \multicolumn{3}{|l|}{$S O F / L D V \pm R B V$} \\
\hline & Pre-treatment & Post-treatment* & $p$ & Pre-treatment & Post-treatment* & $p$ \\
\hline \multicolumn{7}{|c|}{ Laboratory parameters, average (95\% CI) } \\
\hline Total bilirubin, $\mathrm{mg} / \mathrm{dL}$ & $1.1(0.9-1.3)$ & $1.1(0.86-1.3)$ & 0.120 & $1.4(1.2-1.8)$ & $1.6(0.8-2.44)$ & 0.750 \\
\hline Albumin, $\mathrm{g} / \mathrm{dL}$ & $3.8(3.6-3.9)$ & $4.1(4.02-4.26)$ & $<0.001$ & $3.4(3.3-3.6)$ & $3.8(3.6-4.0)$ & $<0.001$ \\
\hline Hemoglobin, $\mathrm{g} / \mathrm{dL}$ & $14.5(14.1-15.0)$ & $14.6(14.1-15.1)$ & 0.891 & $14.1(13.6-14.6)$ & $14.3(13.8-14.8)$ & 0.271 \\
\hline INR & $1.05(1.01-1.08)$ & $1.10(1.07-1.14)$ & $<0.001$ & $1.12(1.08-1.17)$ & $1.19(1.13-1.24)$ & 0.004 \\
\hline $\mathrm{ALT}, \mathrm{IU} / \mathrm{Lt} * *$ & $65(52-79)$ & $22(19.6-25.2)$ & $<0.001$ & $72(59-84)$ & $28(22.3-34)$ & $<0.001$ \\
\hline $\mathrm{AST}, \mathrm{IU} / \mathrm{Lt} * *$ & $64(52-76)$ & $28(25.4-31)$ & $<0.001$ & $86(71-101)$ & $38(33.9-42.6)$ & $<0.001$ \\
\hline Platelets $\mathrm{x} 1000 / \mathrm{mm}^{3}$ & $159(134-185)$ & $166(140-191)$ & 0.072 & $114(96-133)$ & $117(98-136)$ & 0.221 \\
\hline $\mathrm{AFP}, \mathrm{ng} / \mathrm{mL}$ & $10(6.32-13.7)$ & $4.7(3.35-6.22)$ & $<0.001$ & $16(10.1-22.3)$ & $8.2(2.29-14.2)$ & $<0.001$ \\
\hline \multicolumn{7}{|c|}{ Child-Pugh-Score (CPS), $n(\%) * * *$} \\
\hline A (5-6 points) & $18(95.0)$ & $19(100)$ & & $16(50.0)$ & $27(84.4)$ & \\
\hline B (7-9 points) & $1(5.0)$ & $0(0.0)$ & & $14(43.8)$ & $4(12.5)$ & \\
\hline $\mathrm{C}$ (10-15points) & $0(0.0)$ & $0(0.0)$ & & $2(6.2)$ & $1(3.1)$ & \\
\hline Total cirrhosis & $19(100)$ & $19(100)$ & 1.00 & $32(100)$ & $32(100)$ & 0.012 \\
\hline \multicolumn{7}{|c|}{ Serological fibrosis markers } \\
\hline \multicolumn{7}{|l|}{ Cirrhotic patients } \\
\hline FIB-4 & $4.5(3.0-6.0)$ & $3.2(1.9-4.5)$ & $<0.025$ & $7.6(6.3-8.8)$ & $5.4(4.2-6.6)$ & $<0.001$ \\
\hline APRI & $2.3(1.4-3.1)$ & $0.9(0.5-1.3)$ & $<0.001$ & $3.6(2.6-4.8)$ & $1.7(1.4-2.1)$ & $<0.001$ \\
\hline
\end{tabular}


Non cirrhotic, CHC patients

FIB-4

$$
1.5 \text { (1.1-1.9) }
$$

APRI

$0.4(0.3-0.56)$

0.007

$1.2(0.6-1.7)$

$0.5(0.3-0.7)$

0.004 
Table 6(on next page)

Biochemical parameters and clinical data, pre-/post-DAA treatments. 
Table 5:

2 Types of response and characteristics of the patients that either failed DAA-treatment (first two rows) or had detectable viral RNA at

3 the end of DAA treatment (week 12) but finally were responders (week 24).

\begin{tabular}{|c|c|c|c|c|c|c|c|c|c|c|c|}
\hline $\begin{array}{l}\text { Type of } \\
\text { response to } \\
\text { INF } \alpha 2 \mathrm{a} / \mathrm{RBV} \\
2005-2013\end{array}$ & $\begin{array}{l}\text { DAA Treatment } \\
2017\end{array}$ & Gender & Age & $\begin{array}{l}\text { Elastography } \\
\text { (Kpa) }\end{array}$ & $\begin{array}{l}\text { Cirrhosis, } \\
\text { CPS }\end{array}$ & $\begin{array}{l}\text { Viral } \\
\text { subtype }\end{array}$ & $\begin{array}{l}\text { Initial viral } \\
\text { load } \\
\left(\log _{10} \mathrm{IU} / \mathrm{mL}\right)\end{array}$ & $\begin{array}{l}\text { HCV RNA } \\
\text { at week } 12 \\
\text { (end of } \\
\text { treatment) }\end{array}$ & $\begin{array}{l}\text { HCV RNA } \\
\text { at week } 24\end{array}$ & $\begin{array}{l}\text { Type of } \\
\text { response } \\
\text { to DAAs }\end{array}$ & $\begin{array}{l}\text { SVR } \\
12\end{array}$ \\
\hline Null response & OBV/PTV/r/DSV & $\mathrm{M}$ & 59 & 7.3 & No & $1 \mathrm{~b}$ & 6.5 & $\begin{array}{l}\text { Not } \\
\text { detected }\end{array}$ & $\begin{array}{l}1.62 \log _{10} \\
\mathrm{UI} / \mathrm{mL}\end{array}$ & Relapse & No \\
\hline Breakthrough & $\begin{array}{l}\mathrm{OBV} / \mathrm{PTV} / \mathrm{r} / \mathrm{DSV} \\
+\mathrm{RBV}\end{array}$ & M & 33 & 4.3 & No & 1a & 5.7 & $\begin{array}{l}5.29 \log _{10} \\
\mathrm{IU} / \mathrm{mL}\end{array}$ & $\begin{array}{l}5.10 \log _{10} \\
\mathrm{UI} / \mathrm{mL}\end{array}$ & $\begin{array}{l}\text { Null } \\
\text { response }\end{array}$ & No \\
\hline Null response & $\mathrm{OBV} / \mathrm{PTV} / \mathrm{r} / \mathrm{DSV}$ & $\mathrm{F}$ & 50 & 31.4 & $\begin{array}{l}\text { Yes, CPS- } \\
\text { A }\end{array}$ & $1 b$ & 5.7 & *Detected & $\begin{array}{l}\text { Not } \\
\text { detected }\end{array}$ & Responder & Yes \\
\hline Relapse & $\begin{array}{l}\text { OBV/PTV/r/DSV } \\
+\mathrm{RBV}\end{array}$ & $\mathrm{F}$ & 56 & 5.5 & No & $* 1 \mathrm{a}$ & 5.3 & *Detected & $\begin{array}{l}\text { Detected/N } \\
\text { ot detected } \\
\text { at week } \\
364\end{array}$ & Responder & Yes \\
\hline Null response & OBV/PTV/r/DSV & M & 50 & 5.5 & No & $1 b$ & 5.4 & *Detected & $\begin{array}{l}\text { Not } \\
\text { detected }\end{array}$ & Responder & Yes \\
\hline Relapse & OBV/PTV/r/DSV & $\mathrm{F}$ & 52 & 11 & No & $1 \mathrm{~b}$ & 4.3 & *Detected & $\begin{array}{l}\text { Not } \\
\text { detected }\end{array}$ & Responder & Yes \\
\hline Null response & $\mathrm{SOF} / \mathrm{LDV}+\mathrm{RBV}$ & $\mathrm{F}$ & 68 & 22.3 & $\begin{array}{l}\text { Yes, CPS- } \\
\text { A }\end{array}$ & 1a & 5.5 & *Detected & $\begin{array}{l}\text { Not } \\
\text { detected }\end{array}$ & Responder & Yes \\
\hline
\end{tabular}

